\title{
sciendo
}

\section{Contemporary architecture and urban planning of urban multi-family housing, and the state of health of the society}

\begin{abstract}
Introduction. For years, the influence of place of residence on human health has been the subject of interest of researchers from various scientific disciplines. The basic task in shaping space is to create conditions for proper mental and physical development, the experience of beauty, family life, social and individual life. Biotechnology, psychology and sociology, taking into account technical and aesthetic requirements, are the main design criteria for residential buildings. The omission of the most important assumptions in the design of multi-family housing might be very harmful for residents and can be expressed, for example, in poor mood, reduced work efficiency, depression, an increase in the incidence of diseases and even an increase in mortality. Deepening knowledge about proper living conditions is very important in the pro-health aspect.

Aim. An attempt to answer the question to what extent human development and life are subordinated to staying in specific rooms, dwellings, housing estate, district, and finally the city and the entire metropolitan foundation.

Material and methods. This study is for demonstrative purposes based on a review of publications on the quality of life of residents of urban multi-family housing in the aspect of urban planning and architecture.

Results. The correct insolation of residential premises, shapeof the block, the color and texture of the facade, the location and selection of greenery, lawns, paved surfaces and the layout of buildings are just some of the factors affecting the health of residents. Proper design, construction and operation reduce the presence of bacteria and mold fungi, which directly translates into microbiological health risks.

Conclusions. For the proper existence of city dwellers, it is necessary to maximize the use of sunlight and to educate in the proper use of rooms. Raising health conditions, through both proper insolation and the location of flats, "urban interiors", areas between residential buildings, thoroughfares, playgrounds, sports fields, recreational and recreational areas, directly translates into human health.
\end{abstract}

Keywords: architecture, urban planning, residents, health.

DOI: $10.2478 /$ pjph-2019-0008

\section{INTRODUCTION}

Human health, quality of life and the incidence of specific diseases all depend on genetic factors, but to a large extent they are conditioned by the quality of the environment. Man having the ability to shape environmental factors can have a significant impact on the health of the human body. For years, the influence of place of residence on human health has been the subject of interest of researchers from various scientific disciplines. Air quality, lighting, residential indoor temperature, noise, vibration, humidity, fungus, heavy metals, neglect of hygiene, dirt, overcrowding are just some of the factors affecting the incidence of health problems [1].

The main task in the development of space is to create conditions for the proper mental and physical development of people, experience of beauty, as well as family, social and individual life.

Biotechnology, psychology and sociology, taking into account technical and aesthetic requirements, are the main design criteria for residential buildings.
If you forget the most important assumptions in the design of multifamily housing, this can be very harmful for the residents and may be expressed, for example, in malaise, decrease in labor productivity, depression, increase in the incidence of diseases, and even increase in mortality. An unsuitably shaped space can have an impact on the deterioration of human relationships and sociopathic behavior. Gaining more and more knowledge about proper living conditions is very important in the pro-health and pro-social aspect [1,2].

\section{AIM}

The aim of the study is an attempt to answer the question to what extent human development and life are subordinated to staying in specific rooms, dwellings, housing estate, district, and finally the city and the entire metropolitan foundation.

This article is of an illustrative nature, based on a review of available publications on the quality of life of residents of urban multi-family housing in the aspect of urban planning and architecture. 


\section{MATERIAL AND METHODS}

Architecture and urban planning are today key areas of knowledge in terms of housing conditions. Until the mid-twentieth century, thinking about the impact of multi-family housing, its form, shape and layout, on human health was often overlooked. It was only thanks to the postulates of the Athens Charter of 1933 that changed the way of shaping space. Domination of narrow tenement houses, basement and mansard in the old architecture began to be replaced by a rational and healthy living space. The architects' assumptions were mainly based on the slogan "sun, space, greenery". The need to create conditions for the positive neighborly relations was taken into account.

It should be noted that the subject of proper insolation of the place has been interesting for individuals since antiquity. An example of this is the home of the Greek philosopher Socrates. Trapezoidal projection and section of the building was to provide protection against excessive temperatures during the summer and against cold wind in the winter. From the times of antiquity to the nineteenth century, single-family housing prevailed and was the basic form of shelter for people [3].

Along with the emergence of multi-family buildings in the cities, the microclimate of the metropolis and the microclimate in the residential interiors also changed. The city and its urban planning function as one organism. When shaping the space, sunlight or ventilation should be considered together with other buildings, low and high greenery, so-called small architecture, streets, parking lots and topography of the area. There are many factors for urban planning, architecture and its perception. The shapes of the solid, the colors of the facade, the layout of the interiors, the layout and size of the windows, and the layout of greenery affect not only the aesthetic values but, to a large extent, the health and psychophysiological conditions.

Ralph Lewis Knowless, an American professor of architecture and leading theoretician of solar access design, said that "the sun is the foundation of life - this is the source of our vision, warmth, energy and the rhythm of our lives. Light is moving in our perception in time, in space and in the scale of the entire universe. The quality of our life depends on exposure to the sun" [4].

Research on the effects of sunlight on the viability of bacteria, which was first developed by Dawnes and Blount in 1877 , showed interesting results. It turned out that the irradiation of microorganisms with sunlight gives different effects depending on the time of exposure. Long-lasting sunlight causes bacteriostatic and bactericidale ffects, while short exposure speeds up the process of bacterial reproduction [5].

Research in later years has shown the optimal duration of insolation in residential premises. With an insolation of 3-4 hours, the most optimal bactericidal effects are achieved. The test results show how important the window area is, in relation to the room surface and the entire dwelling. Window packages can be equipped with a wide range of glass types. Parameters of heat transmission or sunlight can improve the comfort of living in living rooms. Glass has also a significant impact on blocking noise, which is a source of stress, and consequently can lead to deterioration of health, such as insomnia, feelings of anxiety, etc. The facades of modern residential architecture in metropolises are mostly large glazed, providing not only views of the surrounding environment, but above all, the insolation that causes the so-called healthy living climate $[4,5]$.
Shaping multi-family housing that provides the best possible insolation guarantees a healthy environment in residential interiors, but the comfort of living consists of many other factors present in the design process.

Metropolitan buildings have a direct impact on the microclimate of the housing estate, city or metropolis. The temperature and humidity of rooms depends on the proper planning of the space. Apartments located on the ground floor have a different microclimate than those located on the $10^{\text {th }}$ floor. Buildings surrounded by easily heated buildings have a different comfort of living than those surrounded by greenery. The location of a residential building is of fundamental importance for the comfort of living. Otherwise, the object is located in the valley, and differently on the top of the mountain. Due to topography in design, avoiding shade and valleys prevails. Lower areas can be shaded by surrounding hills and buildings. A very important aspect is airing the city, or "letting in" fresh air and proper management of the used one. Today, in urban planning and architecture, the issue of air pollution is crucial. Many cities are struggling with the problem of so-called smog, actually the problem of every major city on Earth. The phenomenon of polluted air that is present in the urban space, i.e. smog, due to the genesis of formation can be divided into sulfur smog and photochemical smog. Proper spatial planning has a preventive effect on the harmful effects of poor air quality. Including urban aerodynamics causes drafts in the city. The wind movement removes the mass of polluted air, which is why, it is very important to locate buildings in accordance with the prevailing wind directions in a given area and the shape of the objects' solids themselves.

Another very important factor that affects the quality of life and health of urban residents is greenery [6]. The entire existence of man depends on the world of green plants, because only they are capable of biotrans forming the energy of sunlight. In terms of urban design, the dependence of the location of trees, shrubs, green open areas, in addition to aesthetic values is of great importance for the comfort of buildings. Depending on the season, the tree may shade part of the building and prevent excessive heating of the facade, room or area around the building. Trees in the winter season protect against from $30-60 \%$ of the sun's rays. Tree sharpers can direct the wind and protect against excessive gusts. Vegetation in the city absorbs and expels $\mathrm{CO} 2$, the amount and speed of "breathing" of trees depends on the species, light intensity and location. Excessive tree concentration and lack of care, e.g. the removal of fallen leaves may prevent vegetation to many other, lower plants. Excessive shading is conducive to maintaining moisture and creates the opportunity to grow fungi and mold. The location of the grouping of trees, shrubs and lawns, as well as the continuity and connection of greenery enclaves into one ecosystem, have a very large impact on the microclimate of the urban interiors, the space between residential buildings. Municipal greenery requires constant care, cutting out elderly and sick specimens and planting new ones. The city's users, in order to improve comfort and health, should treat the city as a very demanding garden. A well-planned city offers residents some forest areas - a place for recreation and rest surrounded by nature, but located on the outskirts and well communicated. In modern metropolises, flat zones are distinguished from the work zone and the resting zone by green buffers [7].

Maintaining healthy comfort in residential buildings depends on the proper ventilation of the rooms. In the past, 
the rooms were naturally ventilated on the basis of airing rooms. Later, chimneys were introduced and the used air from the interior was drained by gravity, and fresh air from the outside got through the windows and doors. Modern construction offers a mechanical way of ventilating rooms, where the outside air can be cleaned from pathogenic suspensions in the air. You can warm up fresh and cold air coming from the outside (so-called recuperation) with warm, used air. This ventilation method reduces the energy needed for mechanical ventilation and heating of buildings. Modern anti-fog ventilation systems suck in air from the outside, which then flows through a system of absorbers and filters, and only after cleaning the air goes to the rooms. The filters for mechanical ventilation are selected depending on the type of pollution occurring in the air. Ventilation systems, including heating and air conditioning, should be well maintained and cleaned also due to the problem of the rapid growth of bacteria inside the ventilation ducts. In housing, an important aspect is the acoustic comfort of ventilation devices. Experiments and research are currently being carried out in the direction of return to natural ventilation. The so-called wind towers which can bring fresh air, using the pressure difference, from high altitudes first to the level of the underground, and then directly to the apartments [6,7].

Lack of ventilation, poor air quality, presence of dust and biological pollutants that cause physical and psychological discomfort was diagnosed as a Sick Team. Local lesions and general ailments were diagnosed in users of buildings where a faulty ventilation system was used or was incorrectly operated.

The maintenance, proper functioning and maintenance of ventilation or air-conditioning devices allows to obtain proper humidity and air cleanness in the context of biological factors, especially bacteria and mold fungi. Proper use, education of residents, training of technical service personnel can prevent the effects of bad use, especially the emergence of health determinants.

Keeping privacy and at the same time friendly space available to everyone, stability and durability of the structure, adequate natural light, heat, ventilation, access to infrastructure, favorable environmental conditions, the use of healthy building materials in the interiors of flats, easy access to work are factors that affect the behavior health of residents of multifamily housing estates. Health problems related to housing conditions and, above all, the way of designing a housing estate, housing, the use of construction materials and technical equipment directly translate into the health of people who chose to live in the city.

\section{CONCLUSIONS}

For the proper existence of city dwellers, it is necessary to maximize the use of sunlight and education in the proper use of rooms. Raising health conditions, both through proper insolation and the location of flats, "urban interiors", areas between residential buildings, thoroughfares, playgrounds, sports fields, recreational and recreational areas, directly translates into human health.

\section{REFERENCES}

1. Szymborski J. Mieszkalnictwo a zdrowie. Wiadomości PKN. 2008;9:1-9.

2. Bonnefoy $X$. Inadequate housing and health: an overview. Int $J$ Environ Pollut. 2007;30(3-4):411-29.

3. Twarowski M. Słońce w architekturze. Warszawa: Arkady; 1970. p.7-12.

4. Knowless RL. The solar envelope: its meaning for energy and buildings. Energy and Buildings. 2003;35(1):15-25.

5. Lechner N. Heating, cooling, lighting: Design Methods for Architects. John Wiley\&Sons; 2005. p.2-46.

6. Kędzierska I. Kędzierski W. Ekologiczna profilaktyka chorób uwarunkowanych przez czynniki środowiskowe. Warszawa: Wydawnictwo Medyczne; 1997. p.18-29.

7. Marmot AF, Eley J, Stafford M et al. Building health: an epidemiological study of „sick building syndrome” in the Whitehall II study. Occup Environ Med. 2006; 63:283-9.

\section{Corresponding author}

Bartłomiej Jan Kożuchowski

Lublin University of Technology, Faculty of Civil Engineering and Architecture, 38 D Nadbystrzycka St.,20-618 Lublin

E-mail: b.kozuchowski@gmail.com 